\title{
The Effect of the Reliability of Accounting Information Systems on Electronic Disclosures on the Stock Prices: Applied Study on Industrial Companies Listed on Amman Stock Exchange
}

\author{
Thaker A. Syaeid ${ }^{1}$ \\ ${ }^{1}$ Irbid National University, Irbid, Jordan \\ Correspondence: Thaker A. Syaeid, Irbid National University, Irbid, Jordan. E-mail: thakrmassarwa@gmail.com
}

Received: May 22, 2019

Accepted: June 10, 2019

Online Published: June 25, 2019

doi:10.5539/ijef.v11n8p14

URL: https://doi.org/10.5539/ijef.v11n8p14

\begin{abstract}
The study aims at identifying the impact of the reliability of the accounting information systems (security, confidentiality, privacy, the integrity of processes and readiness) on the stock prices of Jordanian industrial companies in Amman Stock Exchange and determining the effect of electronic disclosures (the appropriate timing, predictability and ability to reorganizing) in improving that impact; depending on the descriptive analytical approach, the questionnaire was designed and distributed to the sample of the study composed of directors of financial departments and divisions related to financial issues, monitoring and internal audit and information technology at industrial companies listed on Amman Stock Exchange, with the average of two questionnaires in each company. The number of questionnaires retrieved and statistically analyzed (118), (90.8\%) of distributed questionnaires. The results of the multiple regression analysis showed a statistically significant effect on the reliability of accounting information systems in their dimensions (security, confidentiality, privacy, integrity of processes, and readiness) on the stock prices of Jordanian industrial companies in Amman Stock Exchange, where the moral effect appeared in all dimensions, except (security, integrity of processes). The results of the regression analysis showed that electronic disclosures were represented by (the appropriate timing, predictability and ability to reorganizing) which lead to improve the effect of accounting information systems on the stock prices of Jordanian industrial companies in Amman Stock Exchange. The study recommended to increase the level of interest in the reliability of accounting information systems, and to increase the level of its application and activation in the Jordanian industrial companies, because of its role in improving the performance of the company, and maximize their market value through its accounting information to shareholders of accurate, convenience, timely, reliable, consequently ensuring their survival and continuity, and to increase the awareness of the management of Jordanian industrial companies and financial statements preparers about the importance of electronic disclosure and the benefits it achieves in addition to the resulting risks, and adopt effective procedures to verify the security and reliability of accounting information that electronically disclosed and to transmit the information securely by users.
\end{abstract}

Keywords: accounting information systems, reliability of accounting information systems, electronic disclosures, stock prices

\section{Introduction}

The industrial sector considers being one of the main pillars that play a very important role in supporting and developing the national economy. Because of the importance of this sector on the one hand, and increasing the intensity and magnitude of the challenges of the current era, which cast a shadow on all sectors, organizations and jobs on the other hand; It has become necessary to focus on the attention at accounting information systems and use its latest development, which would contribute to save time and effort and affect the prices of stocks and trading in the financial markets, as an important tool for measuring and reporting on the activities and profitability of organizations and for accounting processes of data in accordance with International Financial Reporting Standards (IFRS). However, this development is accompanied by many risks related to these advanced systems, that many managers, users and decision makers rely on them in general, and investors in particular, in order to obtain accurate information in due course to make rational decisions in the field of investment.

As financial reports are now being disclosed electronically, so that these reports are characterized by quality and reliability by investors in the stock markets, it was necessary to have a reliable electronic accounting information 
system uses by organizations, and to measure its reliability and to increase confidence and daily maintenance, in order to protect investors, by verifying the compliance of accounting information systems with the principles and standards of reliability in order to maintain its credibility.

\subsection{Study Problem}

Financial reporting is the primary source of accounting information systems. As a key function of accounting information systems is to provide financial reports which provide useful information to help decision-makers make decisive decisions. Investors are one of the parties seeking accounting information that meets their needs in the nick of time to make their investment decisions. Although the use of the Internet has made it easier for investors to obtain this information in a timely, cost-effective manner through companies disclosing their accounting information electronically. However, this information does not serve the decision-making process unless it is useful. For accounting information to be of benefit and reliable in decision-making, such information must be accurate and ready when it is needed, and that such systems are protected and reliable.

On this basis, the statement of the research lies in trying to answer the following questions:

1) What is the impact of the reliability of accounting information systems (security, confidentiality, privacy, the integrity of processes and readiness) on the stock prices of Jordanian industrial companies in Amman Stock Exchange?

2) Is there an impact of electronic disclosures (appropriate timing, predictability, and ability to reorganization) in improving the impact of accounting information systems on the stock prices of Jordanian industrial companies in Amman Stock Exchange?

\subsection{Study Objectives}

The study aims at identifying the impact of the accounting information systems (security, confidentiality, privacy, the integrity of processes and readiness) on the stock prices of Jordanian industrial companies in Amman Stock Exchange and determining the effect of electronic disclosures (the appropriate timing, predictability and ability to reorganizing) in improving that impact.

\subsection{Study Importance}

The importance of the study is to support and assist a large number of investors dealing with the stock market in light of the technological development in the accounting systems, by identifying their trust in accounting information systems, and how they affect the prices of Jordanian industrial companies' stocks, in order to increase the control of compliance with the principles of reliability in the accounting information systems for the safety of electronic processors for the data and the work of the company, and the development of accounting information systems which applicable in industrial companies, Which is positively reflected on the Jordanian economy.

\subsection{Study Hypotheses}

The following hypotheses were formulated in order to achieve the research objectives and answer their questions.

H01: There is no statistically significant effect of the reliability of accounting information systems (security, confidentiality, privacy, the integrity of processes and readiness) on the stock prices of Jordanian industrial companies in Amman Stock Exchange.

The following sub-hypotheses are derived from this hypothesis:

H01-1: There is no statistically significant effect of the security of accounting information systems on the stock prices of Jordanian industrial companies in Amman Stock Exchange.

H01-2: There is no statistically significant effect of the confidentiality of accounting information on the stock prices of Jordanian industrial companies in Amman Stock Exchange.

H01-3: There is no statistically significant effect of the privacy of accounting information on the stock prices of Jordanian industrial companies in Amman Stock Exchange.

H01-4: There is no statistically significant effect of the safety of accounting information systems on the stock prices of Jordanian industrial companies in Amman Stock Exchange.

H01-5: There is no statistically significant effect of the readiness of accounting information systems on the stock prices of Jordanian industrial companies in Amman Stock Exchange.

H02: Electronic disclosures do not improve the effect of accounting information systems (security, 
confidentiality, privacy, the integrity of processes, and readiness) on the stocks prices of Jordanian industrial companies in Amman Stock Exchange.

The following sub-hypotheses are derived from this hypothesis:

H02-1: The appropriate timing does not lead to improve the effect of accounting information systems (security, confidentiality, privacy, the integrity of processes, and readiness) on the stocks prices of Jordanian industrial companies in Amman Stock Exchange.

H02-2: Predictability does not lead to improve the effect of accounting information systems (security, confidentiality, privacy, the integrity of process and readiness) on the stocks prices of Jordanian industrial companies in Amman Stock Exchange.

H02-3: Reorganization does not lead to improve the effectiveness of the reliability of accounting information systems (security, confidentiality, privacy, the integrity of processes and readiness) on the stocks prices of Jordanian industrial companies in Amman Stock Exchange.

\subsection{Study Model}

In order to achieve the research's purpose and to reach its specific objectives, the researcher adopted the following model to study the relationships of the variables of the study. The following figure shows the proposed model:

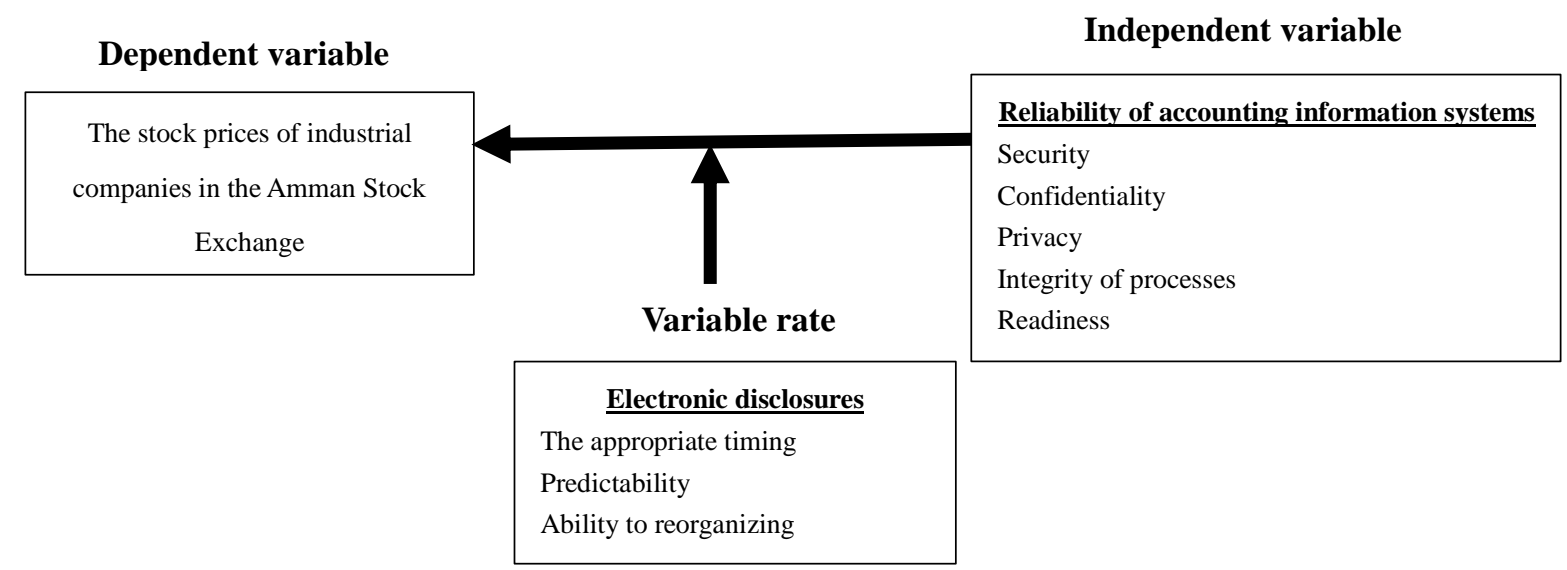

Figure 1. Research model (the source is set by the researcher)

\section{Theoretical Framework}

\subsection{Reliability of Accounting Information Systems}

Information systems are one of the main resources of business organizations, and they are the most distinctive, as they contribute to transforming inputs into outputs, and the organization grants a unique competition which is characterized by other organizations which belong to the same sector (Mata et al., 1996). It also plays an important role in supporting the decision makers in the organization, and control its activities and operations, in addition to supporting the human resources that work in the organization as managers and workers in the face of problems and obstacles to work and find the appropriate solutions (Loudon \& Loudon, 2008).

Accounting information systems are part of the overall information system and play an important role in providing the Organization's decision-makers with the correct and accurate information right on time in the form of reports and financial statements inspired by the actual daily reality of the data. They are defined as the systems for collecting, recording and processing operational data, and transfer them to financial information, then stores it with the aim of providing decision-makers and the parties involved for use in the decision-making process (Kieso et al., 2013). It consists of six core components that are fundamental to the implementation of the activities and processes of the organization, they are represented by individuals who are responsible for managing the system, controlling its work and performing various functions, and data relating to the activities and operations of the Organization, and the procedures for the collection, operation and storage of data related party transactions of the organization, and the software which uses to run the Organization's operations, as well as the means, equipment and techniques that support the operation of accounting information systems, and the procedures to ensure the security and archiving of information (Romney \& Steinbart, 2015). The importance of the accounting information systems appear from the importance of its functions as collects and records data 
related to the activities and transactions of the organization and processing them to turn them into useful information that is highlighted in reports and financial statements used in the decision-making process to plan and control the activities and provide the necessary control in order to protect assets (Salehi \& Abdipour, 2011). At present, the importance of accounting information systems has increased where intense competition among organizations has led organizations to strengthen their capacities to support their strategic position and manage decision-making to achieve the competitive advantage that distinguishes it from its competitors and creates value for customers, this is achieved through the adoption of accounting information systems that are compatible with the progress and technological development by providing these systems with software and computer technologies, which contribute to increase the efficiency of data processing and financial operations to provide appropriate, accurate and reliable information, and respond to the requirements of enhancing competitive advantages, support the organization's performance, and generate commercial value (Kontong, 2009).

To enable the accounting system to perform its functions to the fullest, and to achieve its objectives and thus the objectives of the Organization; this system had to be reliable, which indicates that the organization has got a certificate from one of the financial investment companies confirming the integrity of the processes and reliability of the system, and it is consistent with the accounting client's compliance with the principles and standards of reliability services which directly related to all accounting system operations (Arens et al., 2014). American Institute of Certified Public Accountants (AICPA) and The Canadian Institute of Chartered Accountants (CICA) have created the principles and standards for the reliability of accounting information systems which identified in five basic principles (www.webtrust.org):

1) Security of the system: which refers the control of access to the accounting system and its data, and provides protection against illegal access whether physically or logically, by follow the organization a set of policies, practices and techniques that contribute to providing a reasonable and certain degree of security in electronic business circulation across networks and all activities and movements at risk of penetration (Robinson \& Volonino, 2004). The high level of the security of the system contributes to reduce risks and threats posed by the immoral use of data, and to reduce risks associated with illegal physical use such as theft and the deliberate destruction of certain components of the system (FFIEC, 2003).

2) Confidentiality: refers to the creation of a set of policies and procedures that ensure the confidentiality of sensitive and special information of the Organization, whether collected, processed or stored, maintained and protected from disclosure by unauthorized persons, as well as determining the responsibility and mechanism of maintenance the system.

3) Privacy: refers to follow appropriate procedures and policies in the collection, use, maintenance and protection of personal information relating to customers and disclosure about them in appropriate ways by determining who is responsible for providing this privacy and accurate documentation thereof, and to establish procedures that ensure for the system to meet the needs of renewable customers.

4) The integrity of processes: which refers to ensure that all procedures are processed, as well as the processing of the accounting information system for data, is processed accurately, complete and timely.

5) Readiness: refers to the ability of the system to meet the overall operational requirements related to the work of the organization that committed in a timely manner, and to implement the activities of the data processing cycle (entry, storage, processing, reporting as efficiently as possible).

Romney and Steinbart 2015 believe that the earlier principles of accounting information systems reliability are interlinked and contribute to the overall objective of systems reliability, the principle of protection is the fundamental principle of systems reliability, as Security measures restrict access to the system to authorized users only, thus preserving the confidentiality of the Organization's sensitive data and the privacy of personal information which relates to customers, these procedures also ensure the integrity of processes by preventing unauthorized transactions or altering stored data and programs, as well as their role in preventing intrusion prevention, thus ensuring system readiness when needed.

\subsection{Internet Financial Reporting (Electronic Disclosure)}

The end of the twentieth century has appeared the progress and development of the (Information and Communication Technology ICT) systems. This has been accompanied by great growth in the use of the internet in the business world. The global companies and markets have tended to use the Internet and websites to publish their financial reports and provide financial information to the stakeholders, as it provides many advantages such as high speed in the delivery of information, and accessibility and low cost of obtaining them, which is called the Internet Financial Reporting (IFR) or electronic disclosure (Purba et al., 2013) 
This term has attracted the interest of many researchers and associations and they have given many definitions that explain its content, the International Accounting Standards Committee (IASC), 2010 defined it as business organizations publish their general report containing their operations and financial information using the World Wide Web or any modern and developed technologies. The Financial Accounting Standards Board (FASB), 2000 defined it as the company discloses its financial information and the information of its performance using Internet technology. (Shukla \& Gekara, 2010) defined it as view comprehensive information about the Company's financial and non-financial reports and social and environmental issues through its website or through a link to another site. Khan \& Ismail defined it as publish of the comprehensive financial report including the final accounts and the auditor's report and any information related to the financial performance of the company via its website. Alam and Rashid (2014) also defined it as discloses the financial statements and annual reports and its clarifications, whether fully or partially, on the Internet, the Company's website or the financial market.

Electronic disclosure is a distinctive tool in order to report the information, as it provides flexible forms of presentation and reporting of financial data and information, it allows for networking with current and prospective stakeholders, the methods used by companies to view and publish their financial statements on the Internet have varied, some of them tend to publish comprehensive information, while others publish partial information. Good disclosure of core information to stakeholders is a sign of good governance disclosure (Momany \& Pillai, 2013). Hasbroek and Toit (2003) have justified the reason for the increased demand by organizations to use electronic disclosure is the many advantages that this type of accounting disclosure achieves both for the organization and for users.

For the organization, the main advantages of electronic disclosure are the fact that the Internet is an effective way to connect with potential investors and shareholders and to obtain feedback from stakeholders through the company's website, and to reach the largest segment of society, monitor and track the activity of investors and get the maximum of their interests on the network to improve the site efficiency and increase usage, in addition to update data and information continuously, and the possibility of dissemination additional information on the site explains the company's performance and its development (Khan \& Ismail, 2013).

In relation of the users, the most prominent feature of electronic disclosure is immediate access to the site, access to updated and required information for decision-making from the main source at the right time and at the lowest cost, as well as the possibility to download data and perform the necessary processes and analyzes (Eltkhtash, 2013).

\subsection{The Relationship of Electronic Disclosure with Accounting Information}

FASB 2010 pointed out that relevance and reliability are among the basic characteristics of accounting information which make them useful in the decision-making process, relevance is defined as the extent to which information corresponds with the needs of its users, and the ability of relevant information to make a difference in decisions taken by users. Having this information to be characterized by this feature, it must include predictability and timing, while reliability is defined as free of material errors and represent them faithfully so that users can rely on them, and this feature includes the ability to prove impartiality and honesty.

Electronic disclosure is one of the tools that will enhance some of the characteristics of accounting information, where it provides such information characterized by suitability of all its sub-elements, it supports the predictive and monitoring value of information by providing flexibility in the quality and the volume of information that disclosed, thus enhancing the predictive and monitoring capacities of decision-makers, electronic accounting disclosures are distinguished from other disclosure methods at the appropriate time for disclosure, on the one hand. On the other hand, the electronic disclosure of accounting information may affect negatively of the reliability feature, due to the absence of standards regulating and binding for electronic disclosure, allowing the administration to bias in presenting information to a particular category by selecting the information it wishes to disclose, as well as the risk of accounting information arising from the use of information technology (Haghighi et al., 2015).

\subsection{The Relationship of Electronic Disclosure to Financial Markets}

The disclosure of accounting information, the degree of similarity and transparency of such information, is one of the most important factors that affect the market efficiency (Zhang, 2015), where accounting information disclosed plays an important role in the financial markets due to its huge and strong influence on decisions taken by investors (Sukthomya, 2011), The efficiency of the financial market is determined by the ability of stock prices to represent all available and relevant information to participants in the market (Kelikume, 2016). Electronic disclosure is more efficient and effective in providing information to investors when compared to 
traditional disclosure, thus it contributes effectively to enhancing the role of financial markets through its adopted methods and techniques to provide the information on the right time, the use of electronic disclosure has got many benefits for different parties (Jackson \& Quotes, 2002).

In addition, the efficiency of the financial market is determined by the ability of the information system that works in the market to deliver information to all investors on time, so as to achieve equality between dealers in obtaining information that reflects the investment opportunities available in the market, which would contribute to create a state of balance in generating earnings to investors, which will positively affect the financial market by enhancing the confidence of dealers, and thus increase the volume of trading and the number of investors, which is done if reliance is placed on electronic disclosure beside the traditional disclosure.

\subsection{Accounting Information Role at the Market Price of the Stock}

Accounting information affects directly or indirectly on investor decisions, and stimulate financial markets and increase trading and stock prices, where accounting information is one of the most important things on which investors rely to make their decisions by holding or selling or buying the paper, the behaviour of investors and market participants is affected and the degree of risk tolerance by the nature of the information that reaches the market (Lambert et al., 2006), based on information which received to the market, the expectations change for the share price, in terms of agreeing to a specific price or moving to a new value (Scott, 2003) and new market information leads to a change in trading volume, (Beaver 1968) justified this because the estimates and forecasts provided by dealers in the financial market differ from the new information, resulting in a low consensus on a specific value of the price of the security, thus increasing the volume at the same level as the previous price.

\section{Method}

\subsection{Study Methodology}

This study considers being one of the Applied Studies in solving problems in the field and developing methods of work and productivity in the fields of accounting and management. This study adopts a Descriptive Method that aims at describing certain phenomena or events and collecting information as they actually exist. It also focuses on determining what the phenomena or events that the study should be about by proposing the steps or methods that can be followed in order to reach the image that they should be.

\subsection{Population and the Sample of the Study}

The population study includes all industrial joint stock companies listed on the Amman Stock Exchange which were (62) industrial companies by the end of (2018). A sample of 54 companies was selected, including $87.1 \%$ of the size of the community, this is statistically acceptable according to Sekaran's Tables (2000). The companies were selected by using a random stratified sampling method to ensure that all industries are represented by the number of manufacturing companies in the industrial sector as a whole.

\subsection{Sample Unit}

Directors of financial departments, divisions, internal audit and information technology in each company were targeted and after the distribution of (130) questionnaire with the average of two questionnaires in each company, a total of (121) questionnaires was retrieved, (118) which were analyzed (90.8\%) of distributed questionnaires.

\subsection{Data Sources}

Two main sources of Data Collection have been relied on, they are:

The first includes the literature that dealt with the subject of the study, through reference to the Arab and foreign scientific references from books and related literatures that dealt with topics.

The Second: includes data from its main sources and is divided into two parts:

1) Preliminary data that was collected based on a questionnaire that was designed and includes the variables of the study model.

2) Financial statements issued by industrial companies which published on the Amman Stock Exchange relating to share prices for the period 2015-2017.

\subsection{Statistical Methods Used}

In order to answer the questions of the study and to test the validity of its hypotheses, descriptive and analytical statistical methods were used by using the statistical package (SPSS), to conduct various statistical analyzes and tests. To achieve the objectives of the study, the following statistical methods were used:

1) Descriptive statistic Measures, through percentages, frequencies, arithmetical averages and relative 
importance, to provide a description of the characteristics of the study sample.

2) Cronbach Alfa, in order to verify the amount of consistency coefficient of the study instrument as one of the indicators of the stability of the study tool.

3) The relative importance was determined according to the following formula and according to the Fifth Likert Scale of alternatives for each section:

Relative Importance $=\frac{\text { The highest rate of the alternative }- \text { the lowest rate of the alternative }}{\text { Number of levels }}=\frac{5-1}{3}=1.33$

A. Low if the arithmetic mean is 1.00 to less than 2.33 .

B. Medium if the arithmetic average of 2.33 - to less than 3.66 .

C. High if the arithmetic average is 3.66 - to 5.00 .

4. Test multiple linear correlation to test the validity of the study model.

5. Multiple Regression Analysis to test the effect of the independent variable on the dependent variable.

6. Hierarchical Regression Analysis to test the independent variables on the dependent variable with the modified variable.

\subsection{Test of Content Validity}

The internal coefficient of consistency was calculated as Cronbach's Alpha, where the results were as follows:

Table 1. Values of the internal consistency coefficient of the study tool sections

\begin{tabular}{clc}
\hline No. & Dimension & Alpha Value \\
\hline $\mathbf{1}$ & Systems Security of Accounting Information & $\mathbf{0 . 8 2 5}$ \\
$\mathbf{2}$ & Confidentiality of Accounting Information & $\mathbf{0 . 8 8 8}$ \\
$\mathbf{3}$ & Privacy of Accounting Information & $\mathbf{0 . 9 1 4}$ \\
$\mathbf{4}$ & Operation Safety of Accounting Information systems & $\mathbf{0 . 8 6 4}$ \\
$\mathbf{5}$ & Readiness of accounting information systems & $\mathbf{0 . 8 8 4}$ \\
$\mathbf{6}$ & Reliability of accounting information systems & $\mathbf{0 . 9 5 9}$ \\
$\mathbf{7}$ & The appropriate timing & $\mathbf{0 . 8 6 2}$ \\
$\mathbf{8}$ & Predictability & $\mathbf{0 . 9 1 5}$ \\
$\mathbf{9}$ & Ability to reorganize & $\mathbf{0 . 8 2 8}$ \\
$\mathbf{1 0}$ & Electronic disclosures & $\mathbf{0 . 9 0 1}$ \\
$\mathbf{1 1}$ & All Variables & $\mathbf{0 . 9 7 0}$ \\
\hline
\end{tabular}

Note that Cochranbach alpha coefficient ranged from 0.825 to 0.959 , in addition, the value of Alpha for all variables was (0.970), therefore, all values are greater than 0.60 and this indicates the consistency between the statements of the study instrument and the reliability of the study and the possibility of the study tool for conducting statistical analysis.

\subsection{Description of Responses of the Study Sample}

The mean, the standard deviations, and the relative importance grades were used to describe the responses of the sample members and the results were as follows:

\subsubsection{Reliability of Accounting Information Systems}

Table 2. The mean, standard deviations, ranks and relative importance of the reliability dimensions of accounting information systems

\begin{tabular}{cccccc}
\hline No. & Variable & Mean & Standard deviations & Rank & Relative importance \\
\hline 1 & Security & 4.175 & 0.766 & 3 & High \\
2 & Confidentiality & 4.379 & 0.717 & 1 & High \\
3 & Privacy & 4.129 & 0.845 & 5 & High \\
4 & Integrity processes & 4.155 & 0.776 & 4 & High \\
5 & Readiness & 4.301 & 0.655 & 2 & High \\
Reliability of accounting information systems & $\mathbf{4 . 2 2 8}$ & $\mathbf{0 . 6 6 2}$ & & High \\
\hline
\end{tabular}

From the previous table, we note that the overall average of the reliability of accounting information systems in terms of relative importance is high, where the general average of (4.228) and the standard deviation of $(0.662)$. 
It came after (confidentiality) in the first place with an average of (4.379) and a standard deviation (0.717) with a high relative importance, while (privacy) came in the last place with an average of (4.129) and a standard deviation $(0.845)$ with a high relative importance.

\subsubsection{Reliability of Electronic Disclosure}

Table 3. The means, standard deviations, ranks and relative importance of electronic disclosure dimensions

\begin{tabular}{cccccc}
\hline No. & Variable & Mean & Standard deviations & Rank & Relative importance \\
\hline 1 & The appropriate timing & 3.988 & 0.599 & 1 & High \\
2 & Predictability & 3.976 & 0.562 & 2 & High \\
3 & Ability to reorganize & 3.675 & 0.636 & 3 & High \\
& Electronic disclosure & $\mathbf{3 . 8 7 9}$ & $\mathbf{0 . 5 3 9}$ & & High \\
\hline
\end{tabular}

From the previous table, we note that the overall average of electronic disclosure in terms of relative importance is high, with a general average of (3.879) and a standard deviation of (0.539). It came after (appropriate time) in the first place, with an average of (3.988) and a standard deviation of (0.599) with a high relative importance, while after (the ability to reorganize) came in the last place with an average of (3.675) and the standard deviation (0.636), with a high relative importance.

\subsection{Descriptive Statistics of the Stock Price}

Based on the annual financial statements of Jordanian industrial companies in the Amman Stock Exchange, the descriptive statistics of the variable stock price have been used, for the period from 2015 to 2017.

Table 4. Descriptive statistics of the share price of the Jordanian industrial companies in the Amman stock exchange for the period 2015-2017

\begin{tabular}{lc}
\hline Scale & Variable at stock price $(\boldsymbol{\%})$ \\
\hline Mean & -0.698 \\
Standard deviations & 32.403 \\
High value & 187.406 \\
Minimum value & -41.678 \\
\hline
\end{tabular}

The previous table shows that the mean of the change in the price of stocks of Jordanian industrial companies in the financial market in the period 2015-2017 reached (-0.698), by standard deviation $(32,403)$, the largest observation was (187.406), While the value of the minimum observation was (-41.678). This indicates that there is a significant difference between the Jordanian industrial companies in their stock prices, which may be due to the difference in the sector to which they belong, the nature of the activities and the operations they perform, the size of the companies and their performance and reputation, and may be due to different market trends during the period 2015-2017.

\subsection{Multicollinearity}

In order to test the relevance of the study model for linear regression analysis and parameter tests, multicollinearity was tested, while this phenomenon indicates to perfect linear correlation between two or more variables, it amplifies the $\mathrm{R}^{2}$ selection value and makes it larger than its actual value, therefore, the value of the coefficient was calculated between the independent variables, according to the study model. The results were as follows:

Table 5. Correlation matrix for independent variables

\begin{tabular}{|c|c|c|c|c|c|c|c|c|}
\hline Variable & Security & Confidentiality & Privacy & $\begin{array}{l}\text { The integrity } \\
\text { of processes }\end{array}$ & Readiness & $\begin{array}{c}\text { appropriate } \\
\text { timing }\end{array}$ & Predictability & $\begin{array}{l}\text { Ability to } \\
\text { reorganize }\end{array}$ \\
\hline Security & 1.000 & & & & & & & \\
\hline Confidentiality & $0.686^{* *}$ & 1.000 & & & & & & \\
\hline Privacy & $0.679 * *$ & $0.705^{* *}$ & 1.000 & & & & & \\
\hline The integrity of processes & $0.702 * *$ & $0.721 * *$ & $0.785^{* *}$ & 1.000 & & & & \\
\hline Readiness & $0.638 * *$ & $0.724 * *$ & $0.671 * *$ & $0.752^{* *}$ & 1.000 & & & \\
\hline appropriate timing & $0.675^{* *}$ & $0.709 * *$ & $0.689 * *$ & $0.749^{* *}$ & $0.737 * *$ & 1.000 & & \\
\hline Predictability & $0.598^{* *}$ & $0.688^{* *}$ & $0.523 * *$ & $0.752^{* *}$ & $0.547^{* *}$ & $0.780^{* *}$ & 1.000 & \\
\hline Ability to reorganize & $0.725^{* *}$ & $0.630 * *$ & $0.720 * *$ & $0.620^{* *}$ & $0.509^{* *}$ & $0.405^{* *}$ & $0.662 * *$ & 1.000 \\
\hline
\end{tabular}

Note. $* *$ significant at 0.01 . 
Table 5 shows that the highest correlation coefficient was between the two variables (the integrity of processes) and (privacy), was (0.785), which is less than (0.80), this indicates the absence of multicollinearity phenomenon between variables. The correlation coefficient value which exceeds $(0.80)$ considers to be an indicator of the presence of the high linear correlation problem (Guajarati, 2004, p. 359).

\subsection{Hypotheses Testing}

H01: There is no statistically significant effect of the reliability of accounting information systems in their dimensions (security, confidentiality, privacy, the integrity of processes, and readiness) on the prices of stocks of Jordanian industrial companies in Amman Stock Exchange.

To test this hypothesis, multiple regression analysis was used, and the results were as follows:

Table 6. The results of the effect test (reliability of accounting information systems) on the stock price

\begin{tabular}{|c|c|c|c|c|c|c|c|c|c|c|}
\hline \multirow{2}{*}{$\begin{array}{c}\text { The } \\
\text { dependent } \\
\text { variable }\end{array}$} & \multicolumn{2}{|c|}{ Model Summery } & \multicolumn{3}{|c|}{ Analysis of variance (ANOVA) } & \multicolumn{5}{|c|}{ Coefficients } \\
\hline & $\begin{array}{c}\mathrm{R} \\
\text { Coefficient of } \\
\text { correlation }\end{array}$ & $\begin{array}{c}\mathrm{R}^{2} \\
\text { coefficient of } \\
\text { determination }\end{array}$ & $\begin{array}{c}\mathrm{F} \\
\text { Calculated }\end{array}$ & $\begin{array}{c}\text { Df } \\
\text { Degree of } \\
\text { freedom }\end{array}$ & SigF* & Statement & B & $\begin{array}{l} \\
\text { Std. } \\
\text { Error }\end{array}$ & $\begin{array}{c}\mathrm{T} \\
\text { calculated }\end{array}$ & Sig. $t^{*}$ \\
\hline \multirow{5}{*}{$\begin{array}{l}\text { Stock } \\
\text { Price }\end{array}$} & \multirow{5}{*}{0.727} & \multirow{5}{*}{0.529} & \multirow{5}{*}{61.471} & \multirow{5}{*}{5} & \multirow{5}{*}{0.000} & Security & 0.003 & 0.038 & 0.065 & 0.948 \\
\hline & & & & & & Confidentiality & 0.119 & 0.051 & 2.347 & 0.020 \\
\hline & & & & & & Privacy & 0.144 & 0.039 & 3.666 & 0.000 \\
\hline & & & & & & integrity of processes & 0.041 & 0.053 & 0.779 & 0.437 \\
\hline & & & & & & Readiness & 0.215 & 0.048 & 4.503 & 0.000 \\
\hline
\end{tabular}

Note. $*$ Significant at $(\alpha \leq 0.05)$.

The results of table 6 indicate that the correlation coefficient $(R=0.727)$ refers to the relationship between independent and dependent variables. The effect of the independent variables (Reliability of accounting information systems) on the dependent variable (stock price) is statistically significant, where the calculated $\mathrm{F}$ value is (61.471), with significant level $(\mathrm{Sig}=0.000)$ which is less than 0.05 . The value of the coefficient of determination $\left(\mathrm{R}^{2}=0.529\right)$ was shown to indicate that $(52.9 \%)$ of the variance in the (stock price) could be explained by the variance in the (reliability of accounting information systems).

The table of coefficients showed that the value of B at (safety) was (0.003) with t value (0.062), and significance level ( $\mathrm{Sig}=0.948)$, indicating that the effect of this dimension is insignificant. Accordingly, we accept the first sub-hypothesis which states: "There is no statistically significant effect of the security of accounting information systems on the stock prices of Jordanian industrial companies in Amman Stock Exchange".

The value of $\mathrm{B}$ at the dimension of (confidentiality) was (0.119), the value of $t$ is (2.347) and significance level is $(\mathrm{Sig}=0.020)$, indicating that the effect of this dimension is significant. Accordingly, we reject the second sub-hypothesis which states: "There is a statistically significant effect of the confidentiality of accounting information on the stock prices of Jordanian industrial companies in Amman Stock Exchange"

The value of $\mathrm{B}$ at the dimension of (privacy) was (0.144), the value of $\mathrm{t}$ is (3.666) and significance level is ( $\mathrm{Sig}=$ 0.000), indicating that the effect of this dimension is significant. Accordingly, we reject the third sub-hypothesis which states: "There is a statistically significant effect of the privacy of accounting information on the stock prices of Jordanian industrial companies in Amman Stock Exchange"

The value of $B$ at the dimension of (integrity of processes) was (0.041), the value of $t$ is (0.779) and significance level is $(\mathrm{Sig}=0.437)$, indicating that the effect of this dimension is insignificant. Accordingly, we accept the fourth sub-hypothesis which states: "There is no statistically significant effect of the safety of accounting information systems on the stock prices of Jordanian industrial companies in Amman Stock Exchange"

The value of $\mathrm{B}$ at the dimension of (readiness) was (0.215), the value of $\mathrm{t}$ is (4.503) and significance level is (Sig $=0.000$ ), indicating that the effect of this dimension is significant. Accordingly, we reject the fifth null sub-hypothesis which states: "There is a statistically significant effect of the readiness of accounting information on the stock prices of Jordanian industrial companies in Amman Stock Exchange"

Based on the above discussion, we reject the first main hypothesis and accept the alternative one which states that:

"There is a statistically significant effect on the reliability of accounting information systems in their dimensions (security, confidentiality, privacy, the integrity of operations, and readiness) on the stock prices of Jordanian industrial companies in Amman Stock Exchange" 
H02: Electronic disclosures do not improve the effect of the reliability of accounting information systems (security, confidentiality, privacy, the integrity of processes and readiness) on the stock prices of Jordanian industrial companies on Amman Stock Exchange.

Hierarchical Regression was used in order to test the second main hypothesis and the results were as follows:

Table 7. The results of the hierarchical regression to demonstrate the moderating role of electronic disclosure in the effect of the reliability of accounting information systems combined on stock prices

\begin{tabular}{|c|c|c|c|c|c|c|c|}
\hline \multirow{2}{*}{$\begin{array}{c}\text { Dependent } \\
\text { variable }\end{array}$} & \multirow{2}{*}{ Independent variable } & \multicolumn{3}{|c|}{ The first step } & \multicolumn{3}{|c|}{ The second step } \\
\hline & & B & T calculated & Sig $t$ & B & T calculated & Sig t \\
\hline \multirow{10}{*}{ Stock price } & Security & 0.003 & 0.065 & 0.948 & 0.021 & 0.555 & 0.579 \\
\hline & Confidentiality & 0.119 & 2.347 & 0.020 & 0.110 & 2.206 & 0028 \\
\hline & Privacy & 0.144 & 3.666 & 0.000 & 0.084 & 1.985 & 0.048 \\
\hline & The integrity of operations & 0.041 & 0.779 & 0.437 & 0.027 & 0.524 & 0.600 \\
\hline & Readiness & 0.215 & 4.503 & 0.000 & 0.163 & 3.304 & 0.001 \\
\hline & Electronic disclosure & & & & 0.174 & 3.445 & 0.001 \\
\hline & $\mathrm{R}^{2}$ The coefficient of determination & & 0.529 & & & 0.548 & \\
\hline & $\Delta \mathbf{R}^{2}$ & & 0.529 & & & 0.020 & \\
\hline & $\Delta \mathbf{F}$ & & 61.471 & & & 11.865 & \\
\hline & $\operatorname{Sig} \Delta \mathbf{F}$ & & 0.000 & & & 0.001 & \\
\hline
\end{tabular}

Note. * Significant at $(\alpha \leq 0.05)$.

The above table shows the results of the hierarchical regression which based on two-model. The results of the first model based on the first step reflected a statistically significant effect of the dimensions of the (reliability of the accounting information systems) combined on (stock prices). The value of $(\Delta \mathrm{F}=61.471)$, and significance level is ( $\operatorname{Sig} \Delta \mathrm{F}=0.000)$, which is less than 0.05 , and the value of the coefficient of determination ( $\mathrm{R} 2=0.529$ ). This indicates that the dimensions of the reliability of the accounting information system together account for $(52.9 \%)$ of the variation in (stock prices).

In the second step, the variable (electronic disclosure) of the regression model was introduced, with the increasing of the value $\mathrm{R} 2$ by $(2.0 \%)$, This is a statistical significant, where the value of $(\Delta \mathrm{F}=11.865)$ and the level of significance ( $\operatorname{Sig} \Delta \mathrm{F}=0.001$ ), which is less than 0.05 . In addition, the value of $(\mathrm{B}=0.174$ ) at (electronic disclosure) and significance level is (Sig $\mathrm{t}=0.001)$, which confirms the difference in the moral effect of the dimensions of the reliability of accounting information systems on stock prices depending on the variance of electronic disclosure.

We conclude that:

"Electronic disclosures improve the effect of the reliability of accounting information systems (security, confidentiality, privacy, operational integrity and readiness) on the stock prices of Jordanian industrial companies on Amman Stock Exchange."

Table 8. The results of the hierarchical regression to demonstrate the moderating role of appropriate timing in the effect of the reliability of accounting information systems combined on stock prices

\begin{tabular}{|c|c|c|c|c|c|c|c|}
\hline \multirow{2}{*}{$\begin{array}{c}\text { dependent } \\
\text { variable }\end{array}$} & \multirow{2}{*}{ Independent variable } & \multicolumn{3}{|c|}{ The first step } & \multicolumn{3}{|c|}{ The second step } \\
\hline & & B & T calculated & Sig t & B & T calculated & Sig t \\
\hline \multirow{10}{*}{$\begin{array}{c}\text { Stock } \\
\text { price }\end{array}$} & Security & 0.003 & 0.065 & 0.948 & 0.107 & 1.140 & 0.200 \\
\hline & Confidentiality & 0.119 & 2.347 & 0.020 & 0.058 & 3.140 & 0.002 \\
\hline & Privacy & 0.144 & 3.666 & 0.000 & 0.253 & 5.926 & 0.000 \\
\hline & Integrity of operations & 0.041 & 0.779 & 0.437 & 0.129 & 0.631 & 0.568 \\
\hline & Readiness & 0.215 & 4.503 & 0.000 & 0.120 & 2.618 & 0.000 \\
\hline & Appropriate timing & & & & 0.193 & 5.424 & $\mathbf{0 . 0 0 0}$ \\
\hline & $\mathrm{R}^{2}$ The coefficient of determination & & 0.529 & & & 0.662 & \\
\hline & $\Delta \mathbf{R}^{2}$ & & 0.529 & & & 0.133 & \\
\hline & $\Delta \mathbf{F}$ & & 61.471 & & & 29.417 & \\
\hline & $\operatorname{Sig} \Delta \mathbf{F}$ & & 0.000 & & & 0.000 & \\
\hline
\end{tabular}

Note. * Significant at $(\alpha \leq 0.05)$.

The above table shows the results of the hierarchical regression which based on two-model. The results of the 
first model based on the first step reflected a statistically significant effect of the dimensions of the (reliability of the accounting information systems) combined on (stock prices). The value of ( $\Delta \mathrm{F}=61.471)$, and significance level is ( $\operatorname{Sig} \Delta \mathrm{F}=0.000$ ), which is less than 0.05 , and the value of the coefficient of determination ( $\mathrm{R} 2=0.529)$. This indicates that the dimensions of the (reliability of the accounting information systems) together account for $(52.9 \%)$ of the variation in (stock prices).

In the second step, the variable (appropriate timing) of the regression model was introduced, with the increasing of the value $\mathrm{R} 2$ by $(13.3 \%)$, This is a statistical significant, where the value of $(\Delta \mathrm{F}=29.417)$ and the level of significance ( $\operatorname{Sig} \Delta \mathrm{F}=0.000$ ), which confirms the difference in the significant effect of the dimensions of the reliability of accounting information systems on stock prices depending on the variance of appropriate timing. Accordingly, we conclude that:

"Appropriate timing improves the effect of the reliability of accounting information systems (security, confidentiality, privacy, operational integrity and readiness) on the stock prices of Jordanian industrial companies on Amman Stock Exchange."

H02-2: Predictability does not improve the effect of the reliability of accounting information systems (security, confidentiality, privacy, integrity of processes and readiness) on the stock prices of Jordanian industrial companies in Amman Stock Exchange.

Table 9. The results of the hierarchical regression to demonstrate the moderating role of predictability in the effect of the reliability of accounting information systems' combined on the stock prices

\begin{tabular}{|c|c|c|c|c|c|c|c|}
\hline \multirow{2}{*}{$\begin{array}{c}\text { dependent } \\
\text { variable }\end{array}$} & \multirow{2}{*}{ Independent variables } & \multicolumn{3}{|c|}{ The first step } & \multicolumn{3}{|c|}{ The second step } \\
\hline & & B & T calculated & Sig $\mathbf{t}$ & B & $T$ calculated & Sig t \\
\hline \multirow{10}{*}{$\begin{array}{l}\text { Stock } \\
\text { price }\end{array}$} & Security & 0.003 & 0.065 & 0.948 & 0.055 & 1.187 & 0.236 \\
\hline & Confidentiality & 0.119 & 2.347 & 0.020 & 0.104 & 3.008 & 0.003 \\
\hline & Privacy & 0.144 & 3.666 & 0.000 & 0.270 & 6.333 & 0.00 \\
\hline & Integrity of operations & 0.041 & 0.779 & 0.437 & 0.288 & 0.523 & 0.435 \\
\hline & Readiness & 0.215 & 4.503 & 0.000 & 0.035 & 3.589 & 0.000 \\
\hline & predictability & & & & 0.136 & 4.961 & 0.000 \\
\hline & $\mathrm{R}^{2}$ The coefficient of determination & & 0.529 & & & 0.725 & \\
\hline & $\Delta \mathbf{R}^{2}$ & & 0.529 & & & 0.196 & \\
\hline & $\Delta \mathbf{F}$ & & 61.471 & & & 24.607 & \\
\hline & $\operatorname{Sig} \Delta \mathbf{F}$ & & 0.000 & & & 0.000 & \\
\hline
\end{tabular}

Note. $*$ Significant at $(\alpha \leq 0.05)$.

The above table shows the results of the hierarchical regression which based on two-model. The results of the first model based on the first step reflected a statistically significant effect of the dimensions of the (reliability of the accounting information systems) combined on (stock prices). The value of ( $\Delta \mathrm{F}=61.471)$, and significance level is ( $\operatorname{Sig} \Delta \mathrm{F}=0.000$ ), which is less than 0.05 , and the value of the coefficient of determination ( $\mathrm{R} 2=0.529)$. This indicates that the dimensions of the (reliability of the accounting information systems) together account for (52.9\%) of the variation in (stock prices).

In the second step, the variable (predictability) of the regression model was introduced, with the increasing of the value R2 by $(19.6 \%)$, This is a statistical significant, where the value of $(\Delta \mathrm{F}=24.607)$ and the level of significance ( $\operatorname{Sig} \Delta \mathrm{F}=0.000$ ), which is less than 0.05 , the value $(\mathrm{B}=0.136)$ of the (predictability), and the level of significance (Sig $\mathrm{t}=0.000$ ), which confirms the difference in the significant effect of the dimensions of the reliability of accounting information systems on stock prices depending on the variance of predictability. Accordingly, we conclude that:

"predictability improves the effect of the reliability of accounting information systems (security, confidentiality, privacy, the integrity of processes and readiness) on the stock prices of Jordanian industrial companies on Amman Stock Exchange."

H02-3: Reorganizing improves the effect of the reliability of accounting information systems (security, confidentiality, privacy, the integrity of processes and readiness) on the stock prices of Jordanian industrial companies in Amman Stock Exchange. 
Table 10. The results of the hierarchical regression to demonstrate the moderating role of the ability of reorganizing in the effect of the reliability of accounting information systems combined on the stock prices

\begin{tabular}{|c|c|c|c|c|c|c|c|}
\hline \multirow{2}{*}{$\begin{array}{c}\text { Dependent } \\
\text { variable }\end{array}$} & \multirow{2}{*}{ Independent variables } & \multicolumn{3}{|c|}{ The first step } & \multicolumn{3}{|c|}{ The second step } \\
\hline & & B & T calculated & Sig $\mathbf{t}$ & B & T calculated & Sig $t$ \\
\hline \multirow{10}{*}{ Stock price } & Security & 0.003 & 0.065 & 0.948 & 0.032 & 0.499 & 0.681 \\
\hline & Confidentiality & 0.119 & 2.347 & 0.020 & 0.142 & 3.111 & 0.001 \\
\hline & Privacy & 0.144 & 3.666 & 0.000 & 0.055 & 2.567 & 0.020 \\
\hline & Integrity of operations & 0.041 & 0.779 & 0.437 & 0.127 & 0.388 & 0.352 \\
\hline & Readiness & 0.215 & 4.503 & 0.000 & 0.036 & 3.424 & 0.000 \\
\hline & Ability to reorganizing & & & & 0.158 & 3.204 & 0.000 \\
\hline & $\mathrm{R}^{2}$ The coefficient of determination & & 0.529 & & & 0.593 & \\
\hline & $\Delta \mathbf{R}^{2}$ & & 0.529 & & & 0.064 & \\
\hline & $\Delta \mathbf{F}$ & & 61.471 & & & 21.667 & \\
\hline & $\operatorname{Sig} \Delta \mathbf{F}$ & & 0.000 & & & 0.000 & \\
\hline
\end{tabular}

Note. * Significant at $(\alpha \leq 0.05)$.

The above table shows the results of the hierarchical regression which based on two-model. The results of the first model which based on the first step reflected a statistically significant effect of the dimensions of the (reliability of the accounting information systems) combined on (stock prices). The value of $(\Delta \mathrm{F}=61.471)$, and significance level is ( $\operatorname{Sig} \Delta \mathrm{F}=0.000$ ), which is less than 0.05 , and the value of the coefficient of determination $(\mathrm{R} 2=0.529)$. This indicates that the dimensions of (the reliability of the accounting information systems) together account for (52.9\%) of the variation in (stock prices).

In the second step, the variable (ability to reorganizing) of the regression model was introduced, with the increasing of the value $\mathrm{R} 2$ by $(6.4 \%)$, This is a statistical significant, where the value of $(\Delta \mathrm{F}=21.667)$ and the level of significance ( $\operatorname{Sig} \Delta \mathrm{F}=0.000$ ), which is less than 0.05 , the value $(\mathrm{B}=0.158)$ of the (ability to reorganizing), and the level of significance ( $\mathrm{Sig} t=0.000$ ), which confirms the difference in the significant effect of the dimensions of the reliability of accounting information systems on stock prices depending on the variance of reorganizing. Accordingly, we conclude that:

"Ability to Reorganizing improves the effect of the reliability of accounting information systems (security, confidentiality, privacy, the integrity of processes and readiness) on the stock prices of Jordanian industrial companies on Amman Stock Exchange."

\section{Conclusions and Recommendations}

\subsection{Conclusions}

This research concluded with a set of findings which the researcher presents as follows:

1) The high level is appeared of reliability of the accounting information systems in the Jordanian industrial companies in Amman Stock Exchange, where the general mean reached (4.228) which has come after (confidentiality) in the first place, followed by (readiness), then (security) (The integrity of processes), and finally after (privacy), with high relative importance to all dimensions.

2) The high level of electronic disclosure is appeared in the Jordanian industrial companies in Amman Stock Exchange, where the general mean reached (3.879) at a standard deviation of (0.539). It has come after (appropriate time) in the first place, followed by (predictability) in second place, and finally (ability to reorganize) in the third and final place, with a high relative importance to all dimensions.

3) There is a great contrast between the Jordanian industrial companies in their stock prices, which may be due to the nature of the sector to which it belongs and the nature of its activities and operations, and the size of companies and their performance and reputation, and may be due to different market trends during the period (2015-2017).

4) The findings of the first main hypothesis of this study showed that there is a statistically significant effect of the reliability of the accounting information systems in their dimensions (security, confidentiality, privacy, the integrity of processes and readiness) on the stock prices of the Jordanian industrial companies in Amman Stock Exchange, except for (security and integrity of processes).

5) The findings of the second main hypothesis and its sub-hypotheses showed that electronic disclosures represented by (appropriate timing, predictability and ability to reorganizing) improve the effect of accounting information systems in their dimensions (security, confidentiality, privacy, the integrity of 
processes and readiness) on the stock prices of Jordanian industrial companies in Amman Stock Exchange.

\subsection{Recommendations}

Based on the findings, the researcher recommends the followings:

1) Increasing the level of interest in relation of the reliability of the accounting information systems and increase the level of their practice and activation in Jordanian industrial companies because of their role in improving the performance of the company and maximizing its market value through providing the accounting information to the stockholders which is accurate, appropriate, reliable and timely. Accordingly, to ensure their existence and continuity.

2) The industrial companies to hold more courses and training workshops related to the perfect practice of the principles of reliability of accounting information systems, and to raise awareness among the workers in industrial companies at various administrative levels in relation of the importance of these principles and their role in the company's performance.

3) Increase the awareness of the management of Jordanian industrial companies and financial statements organizers about the importance of electronic disclosure and its benefits, in addition to the risks resulting from it through issuing publications and holding training programs which contribute to increase their knowledge regarding to the electronic disclosure and keep up with the latest developments.

4) Establish professional, legislative and legal standards that oblige Jordanian industrial companies in Amman Stock Exchange to provide more electronic disclosure in order to protect investors.

5) Adopt effective procedures in order to verify the security and reliability of the accounting information that disclosed electronically and to transfer it by users in a safe way.

\section{References}

Alam, Z., \& Rashid, K. (2014). Corporate Financial Reporting on the Internet: A Survey of Websites of Listed Companies in Pakistan. The IUP Journal of Corporate Governance, XIII, 17-40.

American Institute of Certified Public Accountants. (2006). Trust Services Principles and Criteria, Incorporating Sys Trust and Web Trust. from http://www.webtrust.org/download/Trust_Services_PC_10_2006.pdf

Arens, A. A., Randal, J. E., \& Mark, S. B. (2014). Auditing and Assurance Services: A Integrated Approach (15th ed.). New Jersey: Prentice Hall - Business Publishing.

Beaver, W. H. (1968). The Information Content of Annual Earnings Announcements. Journal of Accounting Research, 6, 67-92. https://doi.org/10.2307/2490070

Eltkhtash, S. (2013). Internet Financial Reporting in Arab MENA Countries: An International Perspective. Unpublished Ph.D., University of Dundee, UK.

Federal Financial Institution Examination Council (FFIEC). (2003). Information Technology Examination. Handbook, E - Banking Bppklet.

Financial Accounting Standards Board (FASB). (2000). Electronic Distribution of Business Reporting Information. Business Reporting Research Project. Retrieved from https://www.fasb.org/brrp/brrp1.shtml

Financial Accounting Standards Board (FASB). (2010). Qualitative Characteristics of Accounting Information. Statement of Financial Accounting Concepts (2); In Summary of Principal Conclusions.

Haghighi, S., Omidvar, S., \& Fard, H. (2015). Investigating the Web - Based Financial Reporting and its Impact on the Qualitative Characteristics of Accounting Information. International Journal of Biology, Pharmacy and Allied Sciences (IJBPAS), Special Issue, 110-119.

Hasbroek, F., \& Toit, A. (2003). Importance of Digital Annual Reports. South African Journal of Information Management, 5, 1-11. https://doi.org/10.4102/sajim.v5i1.197

International Accounting Standards Committee (IASC). (2010). Business Reporting on the Internet: Research Study. UK, London.

Jackson, R., \& Quotes, P. (2002). Environmental, Social and Sustainability Reporting on the Web: Best Practices. Corporate Environmental Strategy, 9(2), 193-202. https://doi.org/10.1016/S1066-7938(02)00016-7

Kelikume, I. (2016). New Evidence from Efficient Market Hypothesis for the Nigerian Stock Index Using the Wavelet Unit Root Test Approach. The Journal of Developing Areas, 50, 185-197. 
https://doi.org/10.1353/jda.2016.0041

Khan, M., \& Ismail, N. (2011). The Use of Disclosure Indices in Internet Financial Reporting Research. Journal of Global Business and Economics, 3, 157-173.

Kieso, D. E., Weygandt, J. J., \& Warfield, T. D. (2013). Intermediate Accounting (12th ed.). UK: John Wiley and Sons (Asia), Pte. Ltd.

Kontong, K., \& Ussahawanitchakit, P. (2009). Management Accounting Information System Effectiveness and Business Value Creation: An Empirical Study of Thai Listed Firms. Review of Business Research, 9(2), 23-91.

Lambert, R., Christian, L., \& Verrecchia, R. E. (2006). Accounting Information, Disclosure, and the Cost of Capital. Journal of Accounting Research, 45, 385-420. https://doi.org/10.1111/j.1475-679X.2007.00238.x

Loudon, K., \& Loudon, J. (2008). Management Information System (11th ed.). Prentice Hall Int., Inc.

Mata, F. J., William, W. L., \& Barney, J. B. (1996). Information Technology and Sustained Competitive Advantage: A Resource Based Analysis. MIS Quarterly, 19(4). https://doi.org/10.2307/249630

Momany, M. T., \& Pillai, R. (2013). Interne t Financial Reporting in UAE- Analysis and Implications. Global Review of Accounting and Finance, 4(2), 142-160.

Purba, L., Medyawati, H., Silfianti, W., \& Hermana, B. (2013). Internet Financial Reporting Index Analysis: An Overview from the State Owned Enterprises in Indonesia. Journal of Economics, Business Management, 1(3), 281-284. https://doi.org/10.7763/JOEBM.2013.V1.61

Robinson, S., \& Volonino, L. (2004). Principles and Practices of Information Security. Upper Saddle River, Prentice Hall.

Romney, M., \& Steinbart, P. (2015). Accounting Information Systems. New York, USA: Pearson Education.

Salehi, M., \& Abdipour, A. (2011). A Study of the Barriers of Implementation of Accounting Information System: Case of Listed Companies in Tehran Stock Exchange. Journal of Economics and Behavioral Studies, 2(2), 76-81.

Scott, W. R. (2003). Financial Accounting Theory (3rd ed.). Toronto, Canada: Prentice Hall.

Shukla, A., \& Gekara, M. G. (2010). Corporate Reporting in Modern Era: A Comparative Study of Indian and Chinese Companies. Global Journal of International Business Research, 3(3), 42-56.

Sukthomya, D. (2011). The Empirical Evidence of Voluntary Discloser in the Annual Reports of Listed Companies: The Case of Thailand. Unpublished Ph.D. Thesis, University of Nottingham.

Zhang, Y., Zhang, H., \& Seiler, M. (2015). Impact Information of Disclosure on Prices, Volume, and Market Volatility: An Experimental Approach. Journal of Behavioral Finance, 16(1), 12-19. https://doi.org/10.1080/15427560.2015.1000333

\section{Copyrights}

Copyright for this article is retained by the author(s), with first publication rights granted to the journal.

This is an open-access article distributed under the terms and conditions of the Creative Commons Attribution license (http://creativecommons.org/licenses/by/4.0/). 